\title{
The Implementation of Web-Based Patient Registration System at X Hospital
}

\author{
Mudafiq Riyan Pratama ${ }^{1}$, Selvia Juwita Swari², Gamasiano Alfiansyah ${ }^{3 *}$ \\ 1,2,3 Politeknik Negeri Jember, Indonesia \\ "Corresponding author.Email: gamasiano.alfiansyah@polije.ac.id
}

\begin{abstract}
Registration of outpatients at X Hospital is carried out manually. Patients must register by queuing at the registration counter, this will take a long time and be ineffective. The purpose of this study was to implement a web-based outpatient registration information system. The research method used was the waterfall method that consists of the planning, system design, programming, testing, implementation, and maintenance stages. The result of the system created was a web-based outpatient registration system. The results showed that the use of this system can assist patients in registering outpatients. Patients will find it easier to register for outpatient services by using website support technology. In conclusion, the use of a web-based outpatient registration system can help X Hospital in providing health services to patients.
\end{abstract}

Keywords: Hospital, Implementation, Registration, System

\section{INTRODUCTION}

A hospital is a health service facility that provides comprehensive outpatient, inpatient, and emergency services [1], [2]. One indicator of a hospital's success is the number of outpatients, which indicates the public's trust in conducting medical examinations at the hospital. However, registration of outpatients at X hospital is still carried out manually.

Patients must register and queue at the registration unit before getting health services so that it took a long time and was not effective [3]. In addition, patients also lack information about the days and hours of doctor's practice. This information can only be obtained when the patient comes to the hospital. This level of information management cannot meet the needs of hospital management. This will be an obstacle for hospital development [4]. Therefore, it is necessary to improve the management of outpatient registration at X Hospital, to improve patient waiting times and increase access to information that society needs [5]-[7]. The X Hospital must evaluate the length of time the patient waits until the patient is served. Minimum service standards for hospitals, waiting time for outpatients is not more than 60 minutes [8].

The web-based online outpatient registration system is an effort that can be implemented to overcome problems in outpatient services at X Hospital. The webbased online outpatient registration system is an effort that can be implemented to overcome problems in outpatient services at X Hospital. The urgency of this research is that the system is one of the elements of hospital accreditation assessment as contained in the 2nd chapter of the Access to Hospital and Continuity of Services standard [9]. With this system, $\mathrm{X}$ hospital will get more marks in achieving the National Hospital Accreditation Standard (SNARS 1), and the registration system can improve the quality of outpatient services [10].In addition, this system is useful for helping people register health services at hospitals, ascertain the doctor's practice schedule, and reduce waiting time for patients in the hospital, thereby reducing the potential for Covid-19 transmission, considering that the hospital is one of the clusters of Covid-19 transmission.

The purpose of this study was to implement a webbased outpatient registration system based on SNARS 1 at X Hospital. The research method used is the waterfall approach which has steps including planning, system design, programming, testing, and implementation and maintenance [11]. The implementation of this information system is in accordance with the vision and mission of $\mathrm{X}$ hospital, the realization of an excellent $\mathrm{X}$ hospital, professional and modern in the field of health services, provide infrastructure facilities in accordance 
with technological developments, and develop effective service systems and procedures.

\section{RESEARCH METHOD}

This research used the waterfall method that consists of several stages such as analysis, design, implementation, testing, deployment, and maintenance. However, this article only examined the implementation stages of a web-based patient registration system at $\mathrm{X}$ Hospital. Implementation is the stage of creating the system according to the design that was made in the previous stages. Implementation of a web-based system using the PHP programming language by implementing the CodeIgniter 4 Framework. CodeIgniter 4 is one of the best frameworks in web-based application development that has advantages in terms of security and speed.

\section{RESULTS}

The web-based outpatient registration system was built to make it easier for patients to register for health services, as certain doctor's practice schedules, and reduce waiting time for patients in hospitals, thereby reducing the potential for Covid-19 transmission. System implementation was carried out based on the results of system design in the previous stage. The results of implementing a web-based patient registration system are explained below.

\subsection{Patient Register Page Display}

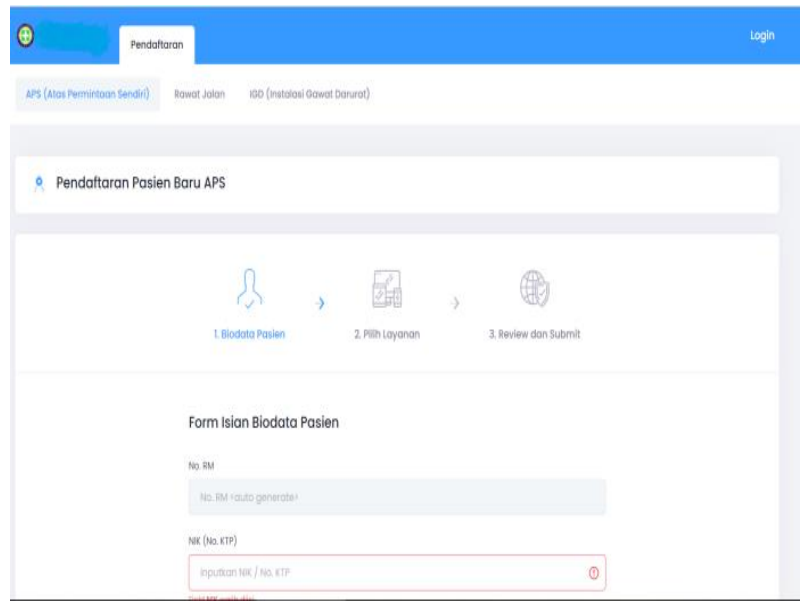

Figure 1. Patient Registration Form

The register form is a form that must be filled out when a patient registers for health services at the hospital. The patient registration form consists of registration of new patients at their own request, outpatients, and emergency patients. Based on Figure 1, to register as a new patient at his own request, outpatient, and emergency patient, the patient must enter some data. The data includes the identity card number, patient's name, place of birth, date of birth, last education, religion, and home address. Filling out the outpatient registration form is shown in the following figure.

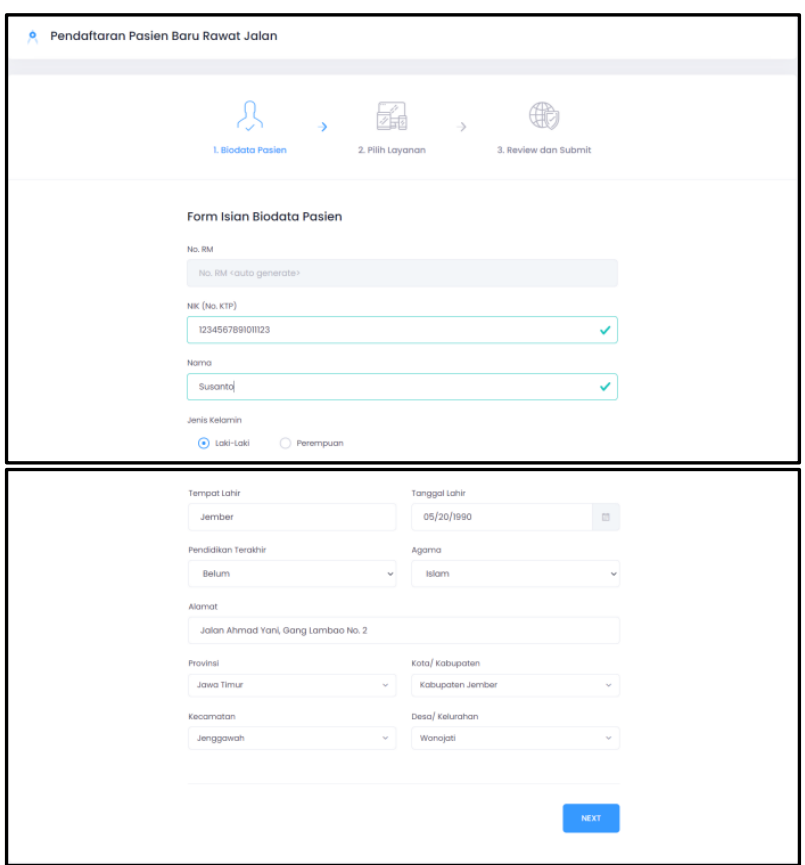

Figure 2. Filling Out Outpatient Data

The next step is to choose a health clinic service. There are several health services options at the clinic including THT clinics (health services for ears, nose and throat), obstetrics clinics, dental clinics, surgery clinics, internal medicine clinics, eye clinics, ECG (electrocardiography) clinics, pediatric clinics, general clinics, and a VCT (Voluntary Counseling and Testing) clinic.

The next step is for the patient to write down his health problem, for example, the patient vomits in the morning. Then the system will display the registration fee and the patient pays the registration fee by transfer to the hospital account number. The next step is for the patient to upload proof of the transfer of the registration fee in the form provided.

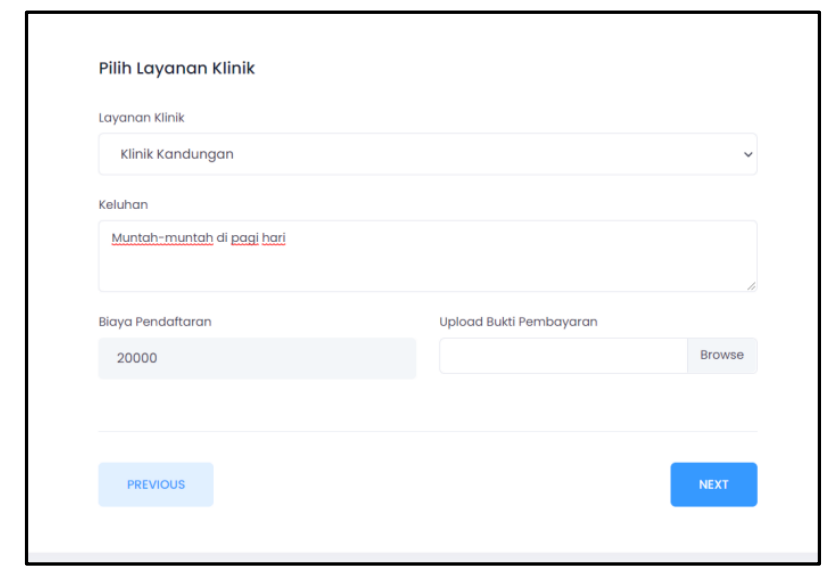

Figure 3. Patients Choose Clinic Services 
The next step is for the patient to review the data that has been entered. This is shown by the following Figure.

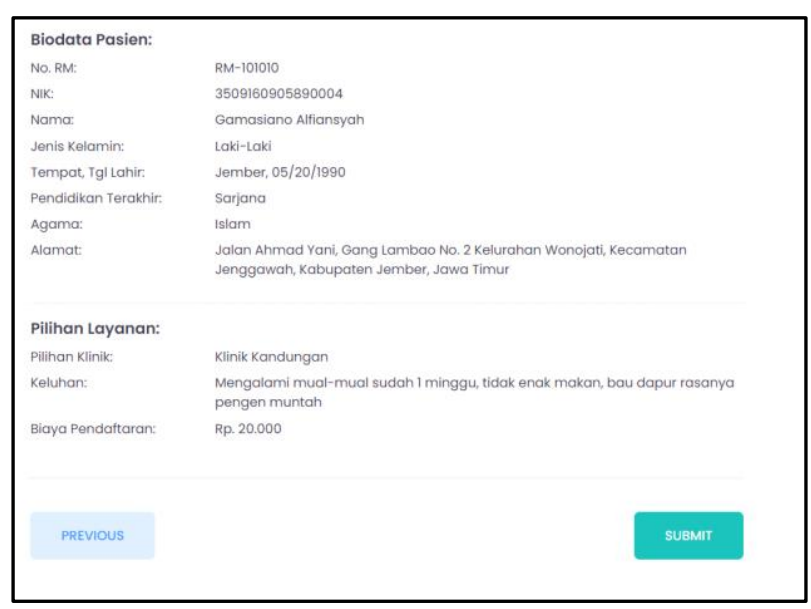

Figure 4. Patient Data Review

If the data entered is correct, the patient can choose the submit option. Then the patient data will be recorded in the hospital queue system. Furthermore, the hospital administration will verify the patient data that has been registered online.

\subsection{Queue Management System}

This menu is a menu for registration officers. Through this menu, officers can verify registrant data through the "antrian pasien" menu. The next step is to click on the verification process, then the patient will get the queue number information through the user page. This is shown by the following Figure.
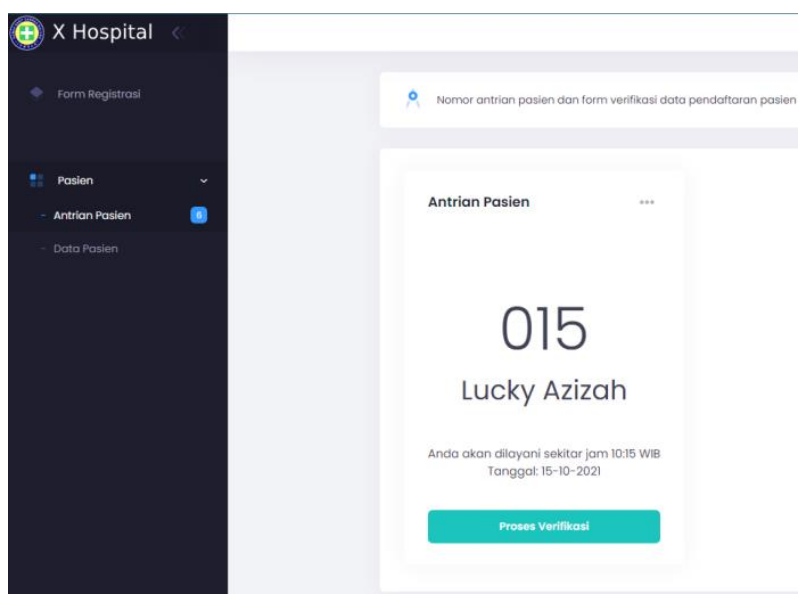

Figure 5. Patient Queue X Hospital

\subsection{Patient Data Management}

Registration officers can perform data management through the "Data Pasien" menu. Through this feature, officers can change data and view patient registration history.

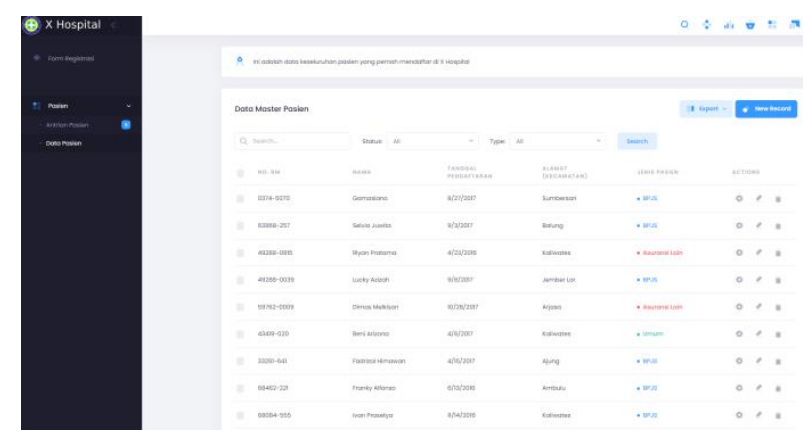

Figure 6. Patient Data Management Menu

After the implementation stage, the next stage is the testing stage. At the testing stage, the system functionality was tested using blackbox-testing. The test results can be seen in the following table.

After the implementation stage, the next stage is testing. At this stage, the system functionality is tested using blackbox-testing. The test results can be seen in the following table.

Table 1. System Testing Results

\begin{tabular}{|c|l|c|}
\hline No. & \multicolumn{1}{|c|}{ Feature } & Result \\
\hline 1. & Biodata form & Success \\
\hline 2. & Choose services & Success \\
\hline 3. & $\begin{array}{l}\text { Review registration data and } \\
\text { submit }\end{array}$ & Success \\
\hline 4. & $\begin{array}{l}\text { Verify registrant data by } \\
\text { registration officer }\end{array}$ & Success \\
\hline 5. & Patient data management & Success \\
\hline
\end{tabular}

The next stage is the deployment stage. Deployment is the stage of installing this system on a server at $\mathrm{X}$ Hospital. At this stage, the data had been uploaded and imported data from the legacy system to the new system, especially for the previous patient data. The last stage of the Waterfall method is the maintenance stage. At this stage, monitoring of the implementation of the system is carried out. If there is a problem with the system, the system will be repaired immediately.

\section{CONCluSion}

The patient registration system at $\mathrm{X}$ Hospital was developed using the PHP programming language with the CodeIgniter 4 framework. System development is carried out using the Waterfall method. This method has been proven to be used for the development of a patient registration system at X Hospital. The use of a web-based patient registration system can improve health services to the patients and increase patient satisfaction in $\mathrm{X}$ hospital.

The testing phase has been carried out using blackbox testing by testing the functionality of the features. The 
result is that the system has run well. However, further testing is needed regarding system security, so that patient data can be maintained.

\section{AUTHORS' CONTRIBUTIONS}

Gamasiano Alfiansyah carried out research concept, conducting research, and report writing. Mudafiq Riyan Pratama carried out research concept, conducting research, system design, and implementation system. Selvia Juwita Swari carried out research question and conducting research.

\section{ACKNOWLEDGMENTS}

We sincerely thank Ministry of Education, Culture, Research, and Technology Republic of Indonesia for the funding support (funds supported by PNBP 2021), and Politeknik Negeri Jember for funding the research so that this research can be carried out well.

\section{REFERENCES}

[1] Kemenkes, Undang Undang Republik Indonesia Nomor 44 tentang Rumah Sakit, no. April. Jakarta: Sekretariat Negara RI, 2009.

[2] A. K. Malhotra, Hospital Management System: An Evaluation. 2009.

[3] H. N. Sherwin, M. McKeown, M. F. Evans, and O. K. Bhattacharyya, "The Waiting Room 'Wait': From Annoyance To Opportunity," Can. Fam. Physician, vol. 59, no. 5, pp. 479-481, 2013.

[4] B. Brigl, A. Winter, R. Haux, and E. Ammenwerth, Strategic Information Management in Hospitals: an Introduction to Hospital Information Systems. New York: Springer Press, 2011.

[5] J. I. Abdullahi, Introduction to Computer Management Tool. Nigeria Victory Publishers, 2004.

[6] E. H. Shortliffe and J. J. Cimino, Biomedical Informatics: computer Applications in Health Care and Biomedicine. New York: Springer, 2006.

[7] H. Guoqing and Y. Ying, "Integrative Management of Information Resources of Enterprises," J China Soc. Sci Tech Info, vol. 1, 2012.

[8] Kemenkes, Keputusan Menteri Kesehatan Republik Indonesia No 129 tentang Standar Pelayanan Minimal Rumah Sakit. Jakarta: Kementerian Kesehatan Republik Indonesia, 2008.

[9] T. A. Bisono and T. W. A. Putra, Perancangan
Sistem Pendaftaran Pasien Rawat Jalan Rumah Sakit Melalui Short Message Service Gateway (Studi Kasus: RS. Panti Wilasa "Dr. Cipto" Semarang), vol. 16, no. 1. 2018.

[10] Anderson Consulting, The future of European health care. Report for the European Community (HCEC). 1993.

[11] I. Sommerville, Software Engineering, 6th. Jakarta: Erlangga, 2011. 